\title{
An Investigation of the Secular Acceleration of Psychiatric Disorders
}

\author{
Sebastian Lemke1 ${ }^{*}$, Sunka De Vries ${ }^{2}$ \\ ${ }^{1}$ Psychiatry and Psychotherapy Clinic of Jena University Hospital, Germany \\ ${ }^{2}$ Ubbo Emmius Clinic, East Friesia Hospital, Germany \\ Email: Isa.Lemke@med.uni-jena.de
}

Received 4 January 2015; accepted 26 January 2015; published 30 January 2015

Copyright (C) 2015 by authors and Scientific Research Publishing Inc.

This work is licensed under the Creative Commons Attribution International License (CC BY). http://creativecommons.org/licenses/by/4.0/

(c) (i) Open Access

\begin{abstract}
Secular acceleration, for example an increase in height in groups of people over a period of time of more than a century, is a unique, perhaps "ecological" event. In the study presented here, historical patient files from the Jena Psychiatric Clinic were evaluated in relation to the problem of acceleration. A first sampling of 119 patient files for the years 1880-1890 revealed that, for children and adolescents up until the end of their twentieth year of life, the average age at the time of their first admission was 17 years. Compared to this, the first admission of a second sample of 132 patient records for the years 1985-1987 revealed a clearly younger average age at first admission of 11 years. This difference in age was found to be statistically significant. The heights of 14-year-old subjects from the city of Jena for the years 1880 to 1975 obtained from the literature showed a documented increase in height of almost $20 \mathrm{~cm}$. The results of our investigation revealed that, in addition to physical acceleration, there was also an advancement of pathological mental processes in the course of a period of 100 years.
\end{abstract}

\section{Keywords}

Acceleration, Secular

\section{Introduction}

As de Rudder [1] has reported, acceleration is a peculiar "ecological” phenomenon which deserves more attention than has been given to it in recent years. The word acceleration in this sense derives from "accelerare" meaning acceleration or hastening. What is meant by this is the processes which are seen in the increase in height of a group of people over a period of more than a century in so-called "secular acceleration”. Other ma-

${ }^{*}$ Corresponding author. 
nifestations of secular acceleration which have been reported, in addition to changes in body size, amongst others, are also advanced tooth development and early sexual maturity [2]. The isolated acceleration of an individual compared to his or her age group should not be taken into account in this context.

One aspect of this phenomenon which has been repeatedly investigated is the question of whether, parallel to the acceleration of physical development, there is also an associated acceleration of intellectual abilities. Some investigators accept that there is such an association [3]-[5], but others have been unable to show this [6]-[8]. On the basis of the assumption that secular acceleration could also lead to the early appearance of particular diseases, Bennholdt-Thomsen [9] carried out an investigation of patients with chorea minor. From his evaluation of 392 case reports related to the period from 1907 and 1940, he found that the frequency peak for this disease was brought forward from the eleventh to the eighth year of life. In the study presented here, we investigated that the question of whether there was also an advanced appearance of a psychological disorder was also related to secular acceleration, a question which had not been answered in the literature published up until now.

\section{Methods}

An archive of case sheets has been kept at the Jena psychiatric clinic since 1804. The following hypothesis was evaluated using this resource.

"Psychopathological phenomena of childhood and adolescence show an earlier manifestation in the second half of the 20th century than the second half of the 19th century".

Two populations of children and adolescents of an age that included up to completion of the twentieth year of life were included in the study. The following parameters were considered to be decisive reference values for the study:

1) The age of the individual at the time of the first admission with related psychopathology.

2) The age of the individual at the time of the earliest symptom documented in an anamnesis.

The data were recorded in random alternation from the two populations. The legibility and completeness of the files were documented.

Using the distance from the hometown to the clinic and severity of symptoms at the time of admission, the aim was to gain information about respective referral practices. The psychiatric symptoms were scaled independent of the classification systems of the BPRS [10], whereby we assumed an adequate transferability of the psychopathological criteria of adults to the populations referred to, similar for example to [11]. The scaling according to the BPRS was trained, before commencement of the investigation, in a pilot study. In addition, the intellectual abilities of the subjects were documented and the diagnoses made at the time were noted.

As evidence of secular physical acceleration, the heights of the subjects were recorded when possible. The processing of the electronically stored data was carried out amongst other means with the aid of the statistics program SPSS. The U test was used to test the differences of two independent samples. Following alpha adjustment, a significant difference was assumed if alpha $<0.017$ and no significance with alpha $\geq 0.017$.

\section{Results}

A first sample was obtained from 119 medical histories of the children and adolescents first admitted from the years 1880 to 1890. The second sample with 132 files included all first arrivals of children and adolescents from 1985 to 1987. The ages and genders of the subjects at the time of the first admission are shown in Table 1.

The difference in age between the two groups was found to be significant following statistical analysis, but not the difference in gender. The difference in age was also found to be significant when the age of the earliest recorded symptom was subjected to statistical analysis (Figure 1 and Figure 2).

The legibility of the files is shown in Table 2.

The legibility of the available files differed significantly following statistical analysis between the two groups.

The completeness of the files is shown in Table 3.

The completeness of the physicians' reports was found to differ when statistics tests were applied to both samples.

The distance between the hometown of the patients and the clinic were determined with the aid of an electronic route planner (Shell atlas route planner version 5.06). The distances determined in this way were then divided into the categories less than $50 \mathrm{~km}$ and more than $50 \mathrm{~km}$ (Table 4). 


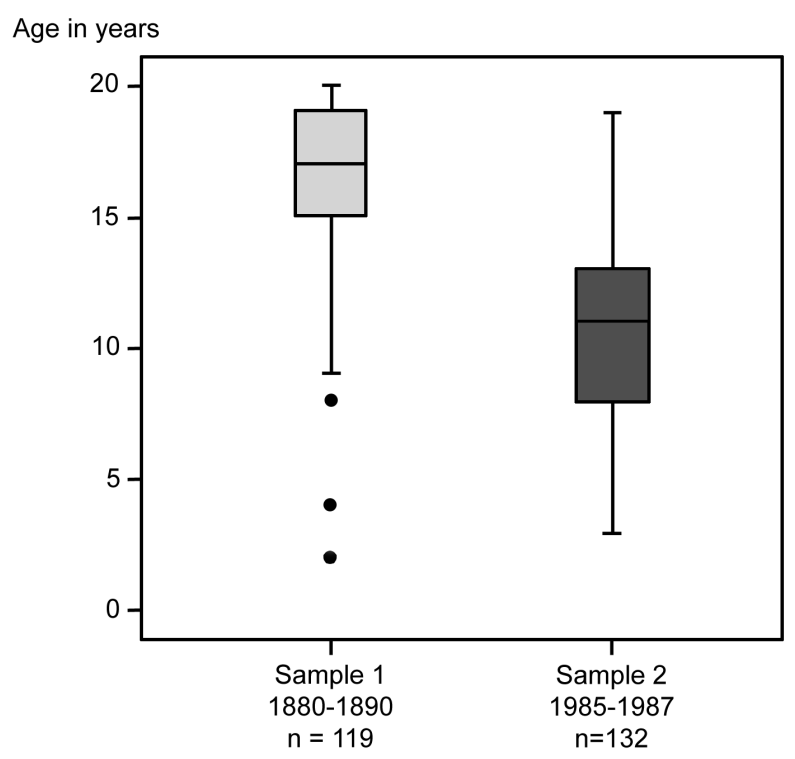

Figure 1. Age differences of the two sample groups at the time of admission as inpatients.

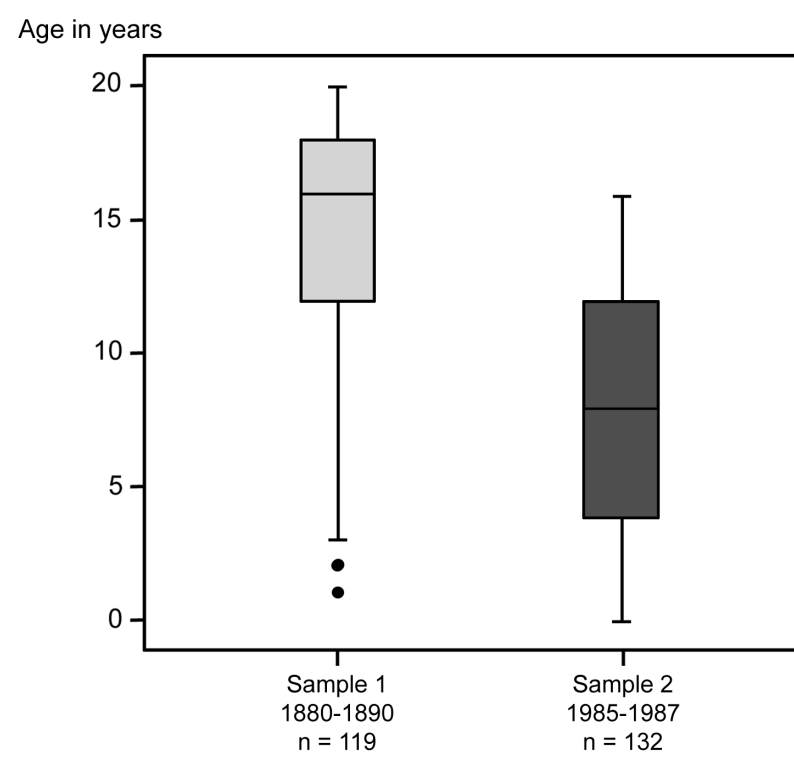

Figure 2. Age differences of the two sample groups at the time of the earliest symptom recorded in an anamnesis.

Table 1. The ages and genders of the subjects at the time of the first admission.

\begin{tabular}{ccc}
\hline & Sample $\mathbf{1}$ & Sample 2 \\
Age and gender & $1880-1890$ & $1985-1987$ \\
& $\mathrm{n}=119$ & $\mathrm{n}=132$ \\
\hline Age (median) & 17 years & 11 years \\
Male (\%) & 61 subjects (51.3\%) & 73 subjects (55.3\%) \\
\hline
\end{tabular}

With reference to the catchment area, the two samples were found to differ significantly following statistical analysis.

The severity of the psychopathological phenomena was determined according to the degree of severity laid 
Table 2. The legibility of the files.

\begin{tabular}{ccc}
\hline Legibility of the file & Sample 1 & Sample 2 \\
& $1880-1890$ & $1985-1987$ \\
$\mathrm{n}=119$ & 132
\end{tabular}

Table 3. The completeness of the files.

\begin{tabular}{ccc}
\hline & Sample 1 & Sample 2 \\
Completeness & $1880-1890$ & $1985-1987$ \\
& $\mathrm{~N}=119$ & $\mathrm{~N}=132$ \\
\hline Good & $51(42.9 \%)$ & $88(66.7 \%)$ \\
Average & $59(42.0 \%)$ & $36(27.3 \%)$ \\
Poor & $18(15.1 \%)$ & $8(6.0 \%)$ \\
Total & $119(100 \%)$ & $132(100 \%)$ \\
\hline
\end{tabular}

Table 4. Distance to the place of residence.

\begin{tabular}{|c|c|c|}
\hline Distance to the place of residence & $\begin{array}{c}\text { Sample } 1 \\
1880-1890 \\
\mathrm{n}=119\end{array}$ & $\begin{array}{c}\text { Sample } 2 \\
1985-1987 \\
n=132\end{array}$ \\
\hline Distance from the place of residence $<50 \mathrm{~km}$ & 64 subjects $(57.1 \%)$ & 106 subjects (80.9\%) \\
\hline Distance to the place of residence $>50 \mathrm{~km}$ & 48 subjects $(42.9 \%)$ & 25 subjects $(19.1 \%)$ \\
\hline Total & 112 (for 7 there was no information) & 131 (for 1 there was no information) \\
\hline
\end{tabular}

down in the BPRS. Scaling with stages 5-7 in at least one item of the BPRS was assigned to the category "very manifest”. As shown by Table 5, no significant differences were found between the two populations in relation to severity.

On evaluating the frequency of individual BPRS items, it was found that there were, to some extent, significant differences between the two sample populations. In sample 1, the items "excitement", "affectations" and "unusual content of thought" were associated with a greater intensity, whereas for sample population 2 this was true for "depressive mood", "hostility" and "body related".

With regard to the distribution of age, in sample 1, the item "grand ideas" was amongst the earliest occurring phenomena and, amongst others, the item "hallucinations" to the late-appearing phenomena. In sample 2, the item "grand ideas" did not appear in the age range up to 20 years and the item "hallucinations" was amongst the earliest appearing phenomena.

Details of the intellectual ability of the patients were categorized according to the three groups "above average", "average" and "below average". When results of intelligence tests were available, these were used for the categorization, so that, as the average, the range of IQ values between 80 and 120 was taken. Other assessments without test-dependent intelligence tests were also taken from the files. In the case of some patients, it was not possible to carry out a retrograde assessment (Table 6).

Information about height was only noted in about one third of cases in the files for the first sample (1880-1890), but for $97 \%$ in the files for the second sample (1985-1987). Therefore, it was only possible to make a comparison of heights as an orientation. In the age groups of 15 and 16 year olds, the following information was obtained (Table 7).

Even so, these heights do not contradict the information available regarding 14-year-old students in the city of 
Table 5. Severity.

\begin{tabular}{ccc}
\hline & Sample 2 & Sample 1 \\
Severity & $1880-1890$ & $1985-1987$ \\
$\mathrm{n}=119$ & 132 \\
\hline $\begin{array}{c}\text { Number of patients with at least one severely manifested } \\
\text { BPRS item (level 5 - 7) }\end{array}$ & $91(76.5 \%)$ & $103(78.0 \%)$ \\
\hline
\end{tabular}

Table 6. Intellectual ability.

\begin{tabular}{ccc}
\hline & Sample 1 & Sample 2 \\
Intellectual ability & $1880-1890$ & $1985-1987$ \\
$\mathrm{~N}=119$ & $32(24.2 \%)$ & $74(56.1 \%)$ \\
Number of patients with above average intelligence & $22(19.6 \%)$ & $26(19.7 \%)$ \\
Number of patients with average intelligence & $62(55.4 \%)$ & $28(25.0 \%)$ \\
\hline
\end{tabular}

Table 7. Height.

\begin{tabular}{ccc} 
Height & Sample 1 & $1985-1987$ \\
$1880-1890$ & $165(\mathrm{n}=12)$ & $164=3)$ \\
Height in the 15th year of life $(\mathrm{cm})$ & $158(\mathrm{n}=5)$ & $170(\mathrm{n}=7)$ \\
Height in the 16th year of life $(\mathrm{cm})$ & 158 & \\
\hline
\end{tabular}

Jena since 1880 with representative samples (Table 8).

Table 8 shows the height whilst standing of 14-year-old subjects from the city of Jena [12].

The three most frequent diagnoses in the two samples are summarized in Table 9. The variability of diagnostic formulations is shown to be clearly higher in sample 2.

\section{Discussion}

In the psychiatric literature of the past century, very early mental disturbances in childhood which are comparable to those of adulthood and which recur to some extent in adulthood have been often described (Table 10).

This overview of the individual, particularly early manifestations does not, however, allow any conclusion regarding any secular acceleration. We attempted to provide evidence of secular acceleration of psychiatric disorders on the basis of archived file material. In so doing, it has been shown that, with an interval of about 100 years, the age at the time of first admission has been brought forward by 6 years.

What influences could have brought about this result? There was a similar distribution in gender in the two groups, so that it can be assumed that this parameter is not a significant influence. The legibility of the files was indeed found to differ, but the reference data such as the time of admission and date of birth were not however affected by this. The same was true for the completeness of the case histories, which were perhaps significant for the differentiation of the diagnoses, but not however for the reference data which were important for the hypothesis. The distance between the clinic and the place of residence was significantly different in the two groups. As a cause, it may be assumed that at the time of sample 1 (1880-1890), the density of care was lower and the locations at which care was provided to some extent had to be looked for over a longer distance.

Under these circumstances, it appears not to be justified to conclude that a different admission procedure was followed by doctors and members of the patient's family or that there was a different admissions procedure implemented by the clinic. Contrary to this assumption, there is the comparable severity of the psychiatric findings on admission. Probably it was necessary to have a similar severity of symptoms at the end of the 19th century as at the end of the 20th century in order for the decision to admit a patient to the clinic to be made.

The advancement of the age at the time of the first admission by 6 years demonstrated here confirms the hypothesis we initially formulated. This advancement could be interpreted to be an indication of secular acceleration. 
Table 8. Representative samples.

\begin{tabular}{ccccccccc}
\hline Year & $\mathbf{1 8 8 0}$ & $\mathbf{1 9 2 1}$ & $\mathbf{1 9 3 2}$ & $\mathbf{1 9 4 4}$ & $\mathbf{1 9 5 4}$ & $\mathbf{1 9 6 4}$ & $\mathbf{1 9 7 5}$ \\
\hline Male subjects (cm) & 143.6 & 149.5 & 153.5 & 155.0 & 158.2 & 158.7 & 163.3 \\
Female subjects (cm) & 147.4 & 150.2 & 155.1 & 154.5 & 156.2 & 157.9 & 162.1 \\
\hline
\end{tabular}

Table 9. The three most frequent diagnoses.

\begin{tabular}{|c|c|c|}
\hline & Sample 1 & Sample 2 \\
\hline & $1880-1890$ & 1985-1987 \\
\hline & $\mathrm{N}=119$ & $\mathrm{~N}=132$ \\
\hline Most frequent diagnosis & $\begin{array}{l}\text { Pubertal insanity } \\
\qquad \mathrm{n}=13\end{array}$ & $\begin{array}{l}\text { Depressive reaction } \\
\qquad \mathrm{N}=13\end{array}$ \\
\hline Second most frequent diagnosis & $\begin{array}{l}\text { Paranoia hallucinations } \\
\qquad \mathrm{n}=12\end{array}$ & $\begin{array}{l}\text { Nocturnal enuresis } \\
n=9\end{array}$ \\
\hline Third most frequent diagnosis & $\begin{array}{c}\text { Epilepsy } \\
\mathrm{n}=11\end{array}$ & $\begin{array}{l}\text { Epileptic spectrum disorder } \\
\qquad \mathrm{N}=9\end{array}$ \\
\hline
\end{tabular}

Table 10. Earliest described age.

\begin{tabular}{|c|c|c|c|}
\hline Author & Year & Symptoms & Earliest described age \\
\hline Ziehen [13] & 1904 & $\begin{array}{l}\text { Hebephrenia } \\
\text { Melancholy }\end{array}$ & $\begin{array}{l}\text { 7th year of life } \\
5 \text { th year of life }\end{array}$ \\
\hline Ziehen [14] & 1906 & $\begin{array}{c}\text { Anancasm } \\
\text { Mania }\end{array}$ & $\begin{array}{l}\text { 8th year of life } \\
\text { 10th year of life }\end{array}$ \\
\hline Geisler \& Schröder [15] & 1958 & $\begin{array}{l}\text { Masturbation } \\
\text { Anxiety states }\end{array}$ & $\begin{array}{l}\text { At all ages } \\
\text { Infant age }\end{array}$ \\
\hline Poznanski, Zrull\& Arbor [16] & 1970 & Depression & 3rd year of life \\
\hline Eggers [17] & 1973 & $\begin{array}{l}\text { Schizophrenia } \\
\text { Delusion }\end{array}$ & $\begin{array}{l}\text { 3rd year of life } \\
7 \text { th year of life }\end{array}$ \\
\hline Kappes [18] & 1981 & Extended attempt at suicide & 6 th year of life \\
\hline Schreier [19] & 1986 & Hallucinations & 2nd year of life \\
\hline Nicolsen et al. [20] & 2001 & Childhood psychosis & 7th year of life \\
\hline
\end{tabular}

It occurred, without doubt, parallel to a continual increase in height by 15 - $20 \mathrm{~cm}$ in 14-year-old boys and girls of the city of Jena, which took place in the course of 100 years.

From the correlation established between the advancement of bodily growth processes and the bringing forward of pathological mental processes, the question is now raised of the extent to which the manifestation of mental disorder requires a certain degree of maturity. The current literature allows the conclusion that, for example, hallucinations are possible earlier than delusional phenomena. i.e., it could need a different degree of maturity of the brain as a prerequisite, (comparing Schreier [19] and Nicolson et al. [20]).

In contrast to this is the finding that, in sample 1 (1880-1890), hallucinations are amongst the last phenomena and grand ideas, in contrast to sample 2, the earliest. Possibly, a maturity-dependent process contributes to the change in the manifestation over long periods of time. The question which is raised about the relationship between processes of maturing and the facilitation of mental disorder cannot be definitely answered.

\section{References}

[1] de Rudder, B. (1960) Zur Frage nach der Akzelerationsursache. Deutsche Medizinische Wochenschrift, 85, $1193-1196$. http://dx.doi.org/10.1055/s-0028-1112561

[2] Bennholdt-Thomsen, C. (1942) Die Entwicklungsbeschleunigung der Jugend. Ergebnisse der Inneren Medizin, 62, 1153-1237. 
[3] Bober, H. and Scholz, E. (1944) Das Reifungsgeschehen bei Jugendlichen. Zeitschrift für Rassenkunde und die Gesamte Forschung am Menschen, 14, 113-140.

[4] Bogin, B. and McVean, R.B. (1983) The Relationship of Socioeconomic Status and Sex to Body Size, Skeletal Maturation and Cognitive Status of Guatemala City Schoolchildren. Child Development, 54, 115-128. http://dx.doi.org/10.2307/1129868

[5] Stone, C.P. and Barker, R.G. (1937) Aspects of Personality and Intelligence in Post Menarcheal and Premenarcheal Girls of the Same Chronological Ages. Journal of Comparative Psychology, 23, 439-455.

[6] Abernethy, E.M. (1936) Relationships between Mental and Physical Growth. Monographies of Social Researches of Child Development, 1, 44-80.

[7] Honzik, M.P. and Jones, H.E. (1937) Mental-Physical Relationships during the Preschool Period. Journal of Experimental Education, 6, 139-146.

[8] Strickmann, R. (1957) Untersuchungen zur Frage der Beziehung von somatischer und psychischer Entwicklung. Ein Beitrag zum Accelerationsproblem, (Abhandlungen zur Philosophie, Psychologie und Pädagogik 12). Bouvier, Bonn, 21-103.

[9] Bennholdt-Thomsen, C. (1940) Krankheitsdisposition und Entwicklungsbeschleunigung der heutigen Jugend (Untersuchungen über Chorea minor). Klinische Wochenschriften, 19, 1337-1338. http://dx.doi.org/10.1007/BF01764305

[10] Overal, J.E. and Gorham, D.R. (1962) The Brief Psychiatric Rating Scale. Psychological Report, 10, 799-812. http://dx.doi.org/10.2466/pr0.1962.10.3.799

[11] Ryan, N.D., Puig-Antich, J., Ambrosini, P., Rabinovich, H., Robinson, D., Nelson, B., Iyengar, S. and Twomey, J. (1987) The Clinical Picture of Major Depression in Children and Adolescents. Archives of General Psychiatry, 44, 854-861. http://dx.doi.org/10.1001/archpsyc.1987.01800220016003

[12] Jaeger, U. (1980) Biologischer Alterswandel bei Jenaer Schulkindern. Pädagogische Grenzgebiete, 19, 401-413.

[13] Ziehen, Th. (1904) Die Geisteskrankheiten des Kindesalters (2). Reuther und Reichard, Berlin.

[14] Ziehen, Th. (1906) Die Geisteskrankheiten des Kindesalters (3). Reuther und Reichard, Berlin.

[15] Geisler, E. and Schröder, J. (1958) Das nervöse Kind. Münchner Medizinische Wochenschrift, 27, 1038-1041.

[16] Poznanski, E., Zrull, J.P. and Arbor, A. (1970) Childhood Depression. Archives of General Psychiatry, 23, 8-15. http://dx.doi.org/10.1001/archpsyc.1970.01750010010004

[17] Eggers, Ch. (1973) Verlaufsweisen kindlicher und präpuberaler Schizophrenien. Monographie: Grenzgebiete der Psychiatrie. Springer, Berlin. http://dx.doi.org/10.1007/978-3-662-13371-2

[18] Kappes, C.V. (1981) Erweiterter Suizidversuch im frühen Kindesalter. Zeitschrift für Kinder-und Jugendpsychiatrie, 9, 36-43.

[19] Schreier, H.A. (1986) Acute Phobic Halluzinations in Very Young Children. Journal of the American Academy of Child and Adolescent Psychiatry, 25, 574-578. http://dx.doi.org/10.1016/S0002-7138(10)60020-9

[20] Nicolson, R., Lenane, M., Brookner, F., Gochman, P., Kumra, S., Sprechler, L., Giedd, J.N., Thaker, G.K., Wudarsky, M. and Rapoport, J.L. (2001) Children and Adolescents with Psychotic Disorder Not Otherwise Specified: A 2- to 8-Year Follow-Up Study. Comprehensive Psychiatry, 42, 319-325. http://dx.doi.org/10.1053/comp.2001.24573 
Scientific Research Publishing (SCIRP) is one of the largest Open Access journal publishers. It is currently publishing more than 200 open access, online, peer-reviewed journals covering a wide range of academic disciplines. SCIRP serves the worldwide academic communities and contributes to the progress and application of science with its publication.

Other selected journals from SCIRP are listed as below. Submit your manuscript to us via either submit@scirp.org or Online Submission Portal.
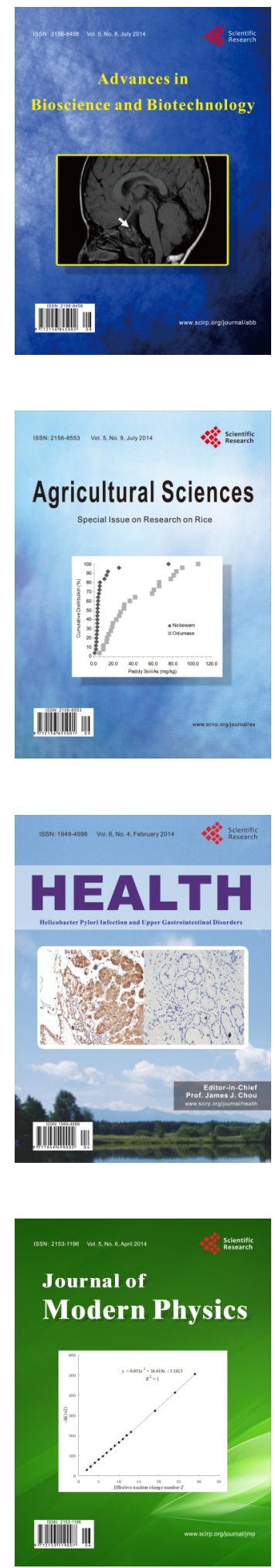
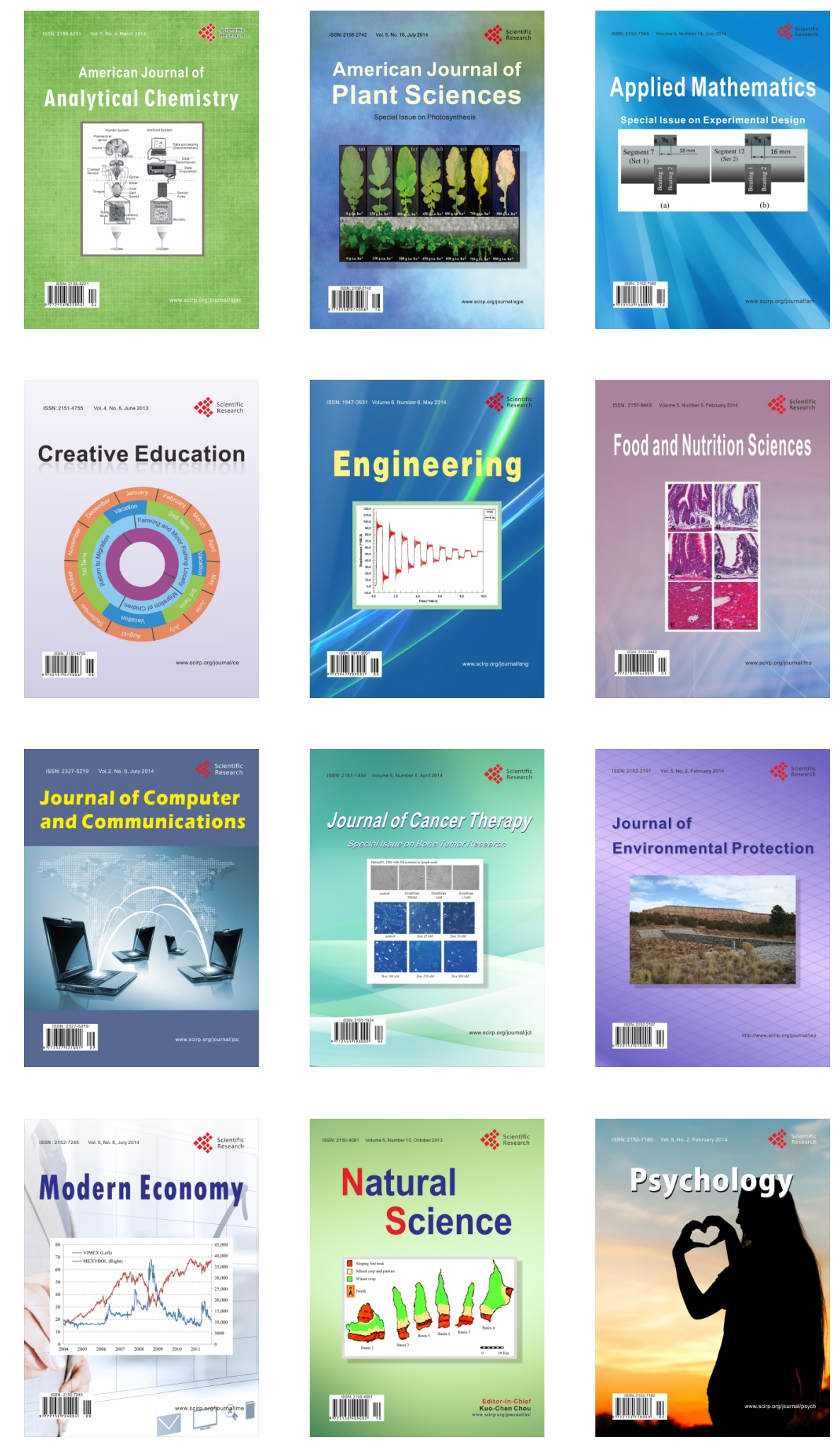